\title{
ANALISIS BERFIKIR TINGKAT TINGGI (Higher Order Thinking) DENGAN MENGGUNAKAN PETA KONSEP PADA POKOK BAHASAN LARUTAN ELEKTROLIT DAN NON ELEKTROLIT
}

Rahmi Hidayati, Imam Santoso, dan Erdawati

Jurusan Kimia Fakultas Matematika dan Ilmu Pengetahuan Alam Universitas Negeri Jakarta Jl. Pemuda No.10

Rawamangun Jakarta Indonesia

\begin{abstract}
Abstrak
Penelitian ini bertujuan untuk mengetahui penggunaan peta konsep dalam mengembangkan kemampuan berpikir tingkat tinggi siswa. Penugasan peta konsep dilakukan secara berkelompok dan menggunakan software C-Map Tools. Oleh karena itu, penilaian dilakukan terhadap peta konsep siswa dan kinerja siswa saat proses pembuatan peta konsep. Metode penelitian yang digunakan adalah penelitian deskriptif. . Data kuantitatif yang dihasilkan dari hasil pembuatan peta konsep siswa dideskripsikan kemudian dianalisis untuk mengetahui perubahan proses berpikir siswa dalam berpikir tingkat tinggi (Higher Order Thinking). Hasil penelitian ini menunjukkan terjadinya perubahan proses berpikir siswa yang ditandai dengan perubahan persentase skor pada setiap kriteria penilaian peta konsep, yaitu penentuan konsep yang relevan, proposisi, hirarki, dan hubungan silang, sehingga kemampuan berpikir tingkat tinggi dapat berkembang dengan pembuatan peta konsep. Berdasarkan penilaian kinerja saat proses pembuatan peta konsep diketahui bahwa sebagian besar siswa sudah memiliki kemampuan manajemen diri, kerjasama, manajemen waktu, menghargai pendapat, pemecahan masalah, dan menyatakan pendapat yang sudah baik. Namun,kemampuan siswa dalam menganalisis pertanyaan dan sikap positif siswa terhadap tugas masih kurang baik.
\end{abstract}

Kata kunci: higher order thinking, peta konsep, larutan elektrolit dan nonelektroli

\begin{abstract}
Abstrack
This research aims to determine the use of concept maps to develop higher order thinking skills of students. Assignment concept map performed in groups and using the software C-Map Tools. Therefore, the assessment of students 'concept maps and students' performance during the process of making a concept map. The research method used is descriptive research. Quantitative data generated from the manufacture of students' concept maps are described and analyzed to determine changes in thought processes of students in higherorder thinking. The results of this study indicate a change students' thinking processes marked with the percentage change scores on each concept map assessment kriteria, that is the determination of the relevant concepts, propositions, hierarchy, and the cross-links, so that higher-order thinking skills can be developed by assigning students create a concept map. Based on the assessment of student performance during the process of mapping concept is known that most students already have a self-management skills, teamwork, time management, respect for opinions, solving problems, and expressed the opinion that good. However, students 'skills in analyzing questions and a positive attitude toward the task is still not good.
\end{abstract}

Key words: higher order thinking, concept maps, electrolyte and nonelectrolyte solutions

\section{Pendahuluan}

Kemampuan berpikir tingkat tinggi merupakan kemampuan yang diperlukan untuk menghadapi era globalisasi yang penuh persaingan saat ini. Menurut Galbreath (1999) pada abad pengetahuan modal intelektual khususnya kecakapan berpikir tingkat tinggi (higher order thinking) merupakan kriteria sebagai tenaga kerja yang handal. Depdiknas juga menegaskan salah satu kecakapan hidup (life skill) yang perlu dikembangkan melalui proses pendidikan adalah keterampilan berpikir. Namun, berdasarkan data dari Human Development Index (HDI) atau Indeks Pembangunan Manusia (IPM) yang menggambarkan tingkat kapabilitas dan kualitas manusia suatu wilayah/negara yang tercermin melalui tingkat kesehatan, pendidikan, dan pendapatan per kapita menunjukkan bahwa peringkat Indonesia selama sepuluh tahun terakhir ini selalu berada pada peringkat seratus kebawah dari 
sekitar 180 negara. Pada tahun 2008 Indonesia menempati peringkat 111 dan tahun 2011 peringkat ke 124 . Penyebab rendahnya mutu pendidikan salah satunya adalah kurangnya upaya pemberdayaan kemampuan berpikir siswa selama proses pembelajaran.

Kemampuan berpikir tingkat tinggi merupakan keterampilan yang dapat dilatihkan dengan menciptakan suasanan pembelajaran yang mempertimbangkan keterlibatan siswa dalam proses pembelajaran sehingga siswa akan terangsang untuk meningkatkan kemampuan berpikirnya. Selain itu, menurut Alice Thomas (1999) kemampuan berpikir tingkat tinggi akan terjadi ketika seseorang mengaitkan informasi baru dengan informasi yang sudah tersimpan didalam ingatannya dan menghubungkannya serta mengembangkan informasi tersebut untuk mencapai suatu tujuan ataupun menemukan suatu penyelesaian dari suatu keadaan yang sulit dipecahkan. Oleh karena itu, salah satu strategi pembelajaran yang dapat digunakan untuk memberdayakan kemampuan berpikir tingkat tinggi adalah dengan peta konsep. Pada pembelajaran dengan peta konsep, siswa akan membangun keterkaitan antara berbagai konsep bahan pembelajaran. Melalui strategi pembelajaran semacam itu sebenarnya siswa selalu digiring untuk menemukan hubungan atau keterkaitan antar konsep. Melalui peta konsep siswa dapat membangun pemahaman yang bersifat konseptual, dan dengan demikian siswa dapat mencapai hasil belajar kognitif atas, yaitu berpikir tingkat tinggi. Peta konsep selain digunakan sebagai sarana pembelajaran juga dapat digunakan sebagai alat penilaian. Tidak seperti tes objektif atau esai yang hanya digunakan untuk menentukan hasil/produk dari hasil pembelajaran, peta konsep dapat digunakan untuk mengetahui pola berpikir siswa. Oleh karena itu, peta konsep dapat digunakan sebagai salah satu bentuk penilaian alternatif untuk mengembangkan kemampuan berpikir tingkat tinggi siswa.

Materi larutan elektrolit dan nonelektrolit di SMA dipelajari di kelas $X$ semester 2 . Berdasarkan analisis materi pelajaran, materi ini tergolong bersifat konseptual. Untuk memahami materi ini siswa harus memahami konsep dengan baik dan mengetahui jalinan antar konsep. Berdasarkan uraian di atas, maka penulis merasa tertarik untuk melakukan penelitian mengenai analisis berpikir tingkat tinggi dengan menggunakan peta konsep pada materi larutan elektrolit dan nonelektrolit.

\section{Metodologi Penelitian}

Penelitian ini menggunakan metode deskriptif, yaitu suatu penelitian yang dilakukan untuk memberikan gambaran mengenai suatu individu, keadaan, gejala atau kelompok tertentu dengan tujuan memperoleh hasil penelitian yang dapat direkomendasikan untuk meningkatkan kualitas proses pembelajaran. Penelitian ini bertujuan untuk mengetahui penggunaan peta konsep dalam proses mengembangkan kemampuan berpikir tingkat tinggi siswa pada pokok bahasan larutan elektrolit dan nonelektrolit. Instrumen yang digunakan dalam penelitian antara lain: peta konsep acuan, soal esai sebagai fokus pertanyaan dalam pembuatan peta konsep, rubrik penilaian peta konsep, dan rubrik penilaian kinerja siswa saat proses pembuatan peta konsep. Peta konsep yang telah dibuat siswa dinilai dengan menggunakan rubrik dengan kriteria penilaian yaitu menentukan konsep yang relevan, proposisi, hirarki, dan hubungan silang. Data yang diperoleh dari rubrik penilaian peta konsep dianalisis dengan melakukan perhitungan persentase data terhadap masing-masing skor (1-4) yang diperoleh untuk setiap kriteria. Perhitungan menggunakan persentase sebagai berikut: 
$\%$ skor $x$

$=\frac{\text { jumlah kelompok yang mendapatkan skor } x}{\text { jumlah total kelompok }}$ $\times 100 \%$

Sedangkan, penilaian terhadap kinerja siswa selama pembuatan peta konsep dihitung dengan cara sebagai berikut:

$$
\begin{aligned}
& \% \text { skor } x \\
& =\frac{\text { jumlah siswa yang mendapat skor } X}{\text { jumlah total siswa }} \\
& \times 100 \%
\end{aligned}
$$

Untuk mengetahui validitas instrumen dapat diperoleh dengan mencari nilai koefisien korelasi. Rumus yang digunakan adalah product moment, sebagai

$$
r_{i t}=\frac{\sum X_{i} \cdot X_{t}}{\sqrt{\sum X_{i}^{2} \cdot \sum X_{t}^{2}}}
$$

Keterangan:

$r_{i t}$ : koefisien korelasi antara skor butir instrumen dengan skor total

$\sum \mathrm{X}_{\mathrm{i}}^{2}$ : Jumlah kuadrat deviasi skor dari $\mathrm{X}_{\mathrm{i}}$

$\sum \mathrm{X}_{\mathrm{t}}^{2}$ : Jumlah kuadrat deviasi skor dari $\mathrm{X}_{\mathrm{t}}$

Reliabilitas instrumen rubrik dihitung dengan menggunakan rumus Alpha Cronbach yaitu

$$
\Gamma_{11}=\left(\frac{n}{n-1}\right)\left(1-\frac{\sum S_{1}^{2}}{S_{1}{ }^{2}}\right)
$$

Keterangan:

$$
\begin{array}{ll}
\Gamma_{11}=\text { koefisien reliabilitas tes } \\
\mathrm{n} & =\text { banyaknya butir item } \\
\sum_{\mathrm{S}_{1}{ }^{2} S_{i}{ }^{2}} & =\text { jumlah varians skor tiap item } \\
& =\text { varians total }
\end{array}
$$

\section{Hasil Penelitian dan Pembahasan}

Instrumen yang digunakan untuk menilai peta konsep siswa terdiri dari peta konsep acuan, soal sebagai fokus pertanyaan dalam pembuatan peta konsep, dan rubrik penilaian peta konsep yang mengacu pada "Novak and
Growin's Scoring for Concept Maps". Sedangkan, rubrik penilaian kinerja saat proses pembuatan peta konsep didasarkan pada rubrik penilaian proses diskusi kelompok, karena pada pembuatan peta konsep ini dilakukan secara berkelompok.

Instrumen yang telah disusun selanjutnya dilakukan penelaahan pakar dan dilakukan uji coba pada kelas yang berbeda dengan kelas penelitian yaitu kelas X.8 dengan jumlah siswa sebanyak 45 orang. Uji coba ini bertujuan untuk mengetahui sejauhmana instrumen tersebut dapat diterapkan untuk menilai kemampuan berpikir tingkat tinggi siswa pada pokok bahasan larutan elektrolit dan nonelektrolit dan menguji validitas instrumen yang telah dibuat.

Uji validitas rubrik penilaian kinerja digunakan uji validitas internal/ validitas butir. Butir yang dianggap valid adalah butir instrumen yang skornya mempunyai koefisien korelasi yang signifikan dengan skor total instrumen. Untuk $n=45$ dengan alpha sebesar 0,05 didapat nilai $r$ tabel yaitu 0,294. Reliabilitas yang didadapat sebesar 0.864 . Berdasarkan perhitungan tersebut terdapat 8 kriteria yang digunakan untuk menilai kinerja siswa selama proses pembuatan peta konsep yaitu: manajemen diri, kontribusi dalam kelompok, menerima pendapat, manajemen waktu, kemampuan memecahkan masalah, kemampuan menganalisis, kemampuan menyatakan pendapat dan sikap positif terhadap tugas.

Hasil uji coba instrumen penilaian peta konsep setelah dikoreksi dan dihitung berdasarkan peta konsep acuan dikatakan valid karena berdasarkan perhitungan memiliki hasil perhitungan diatas $r$ tabel 0,632 dan reliabilitas sebesar 1,106. Berdasarkan hasil perhitungan tersebut dapat disimpulkan bahwa instrumen penilaian peta konsep dapat dipakai. Kriteria penilaian peta konsep, yaitu penentuan konsep yang relevan, proposisi, hirarki, dan hubungan silang. Kriteria 
Tabel 1. Hasil Perhitungan Uji Validitas Rubrik Penilaian Kinerja

\begin{tabular}{|l|c|c|l|}
\hline \multicolumn{1}{|c|}{ Kriteria } & $r_{\text {hitung }}$ & $\begin{array}{c}r_{\text {tabel }} \\
(5 \%, 45)\end{array}$ & Keterangan \\
\hline Manajemen diri & 0.66 & 0.294 & Valid \\
\hline Kontribusi dalam kelompok & 0.64 & 0.294 & Valid \\
\hline Menghargai pendapat & 0.44 & 0.294 & Valid \\
\hline Manajemen waktu & 0.5 & 0.294 & Valid \\
\hline Pemecahan masalah & 0.54 & 0.294 & Valid \\
\hline Analisis pertanyaan & 0.4 & 0.294 & Valid \\
\hline Menyatakan pendapat & 0.55 & 0.294 & Valid \\
\hline Sikap positif terhadap tugas & 0.56 & 0.294 & Valid \\
\hline Kompromi & 0.18 & 0.294 & Tidak Valid \\
\hline
\end{tabular}

penentuan konsep yang relevan menggambarkan kemampuan siswa dalam membedakan informasi dan memahami pengetahuan dasar. Kemampuan menentukan hirarki adalah kemampuan menentukan konsep yang lebih umum dan menentukan konsep turunannya yang lebih khusus, untuk dapat menentukan hirarki diperlukan kemampuan untuk menganalisis. Proposisi adalah hubungan antara dua konsep atau lebih dengan menggunakan kata penghubung, Sedangkan hubungan silang adalah menentukan proposisi antar konsep yang berbeda hirarki. Untuk dapat menentukan proposisi dan hubungan silang diperlukan kemampuan untuk mengevaluasi dan mensintesis yang baik,

Subjek penelitian ini adalah siswa kelas X.1 SMAN 4 Bekasi yang berjumlah 48 orang yang dibagi menjadi 10 kelompok yang terdiri dari 4-5 orang. Penugasan peta konsep dilakukan sebanyak tiga kali, yaitu penugasan pertama mengenai perbedaan antara larutan elektrolit dan nonelektrolit, kedua mengenai hubungan antara jenis senyawa dengan larutan elektrolit dan nonelektrolit, dan ketiga siswa diminta untuk menggabungkan dua peta konsep terdahulu yang pernah dibuat sehingga peta konsep ini diharapkan sebagai perbaikan dari dua peta konsep sebelumnya dan siswa memiliki pengetahuan yang menyeluruh tentang materi larutan elektrolit dan nonelektrolit.

\section{1) Penilaian Peta Konsep}

a. Pembuatan peta konsep pertama

Pada pembuatan peta konsep yang pertama diketahui bahwa kemampuan siswa dalam menentukan konsep yang relevan dan memahami pengetahuan dasar sudah cukup baik, hal ini ditandai dengan persentase kelompok yang mendapatkan skor 3 (terdapat 6-7 konsep dari minimal 10 konsep yang relevan) sebanyak $80 \%$. Banyaknya kelompok yang mendapatkan skor 3 dikarenakan sebagian besar kelompok masih ada yang belum dapat membedakan antara konsep dan bukan konsep, seperti menuliskan "lampu menyala terang" dan "terdapat gelembung gas" sebagai konsep. Pada kriteria penentuan hirarki persentase terbesar berada pada skor 2 (terdapat 2 level dari 5 level hirarki yang tepat) yaitu sebanyak 60\%. Hal ini menandakan kemampuan siswa dalam menganalisis masih kurang baik. Pada kriteria penentuan proposisi persentase terbesar berada pada skor 2 (hanya dapat menentukan 3-4 proposisi yang tepat dari 8 proposisi) sebanyak 70\%. Hal ini menandakan kemampuan siswa dalam menentukan proposisi masih kurang baik. Kesulitan siswa dalam menentukan proposisi adalah dalam menentukan konsep-konsep yang saling berkaitan dan menentukan kata penghubung yang sesuai. Pada penentuan hubungan silang persentase terbesar berada pada skor 1 yaitu sebanyak 60\%. Hal ini menandakan sebagian besar siswa belum 
dapat menentukan hubungan silang antar konsep. Hasil ini menunjukkan bahwa kemampuan berpikir tingkat tinggi siswa masih belum baik.

\section{b. Pembuatan peta konsep kedua}

Pada soal pembuatan peta konsep kedua siswa sudah diberikan beberapa konsep, namun siswa masih harus memilih konsepkonsep yang relevan dengan pertanyaan. Kriteria penilaian pada peta konsep yang kedua ini adalah penentuan konsep yang relevan, proposisi, dan hirarki. Berdasarkan peta konsep acuan pada peta konsep kedua ini tidak ada hubungan silang, namun setelah peta konsep digabungkan atau pada penugasan ketiga dapat terlihat hubungan silang antar konsep.

Pada kriteria penentuan konsep yang relevan persentase terbesar berada pada skor 3 (menentukan 7-9 konsep dari 12 konsep yang relevan) yaitu sebanyak $80 \%$. Berdasarkan hasil tersebut dapat diketahui siswa sudah mampu untuk memilih konsep-konsep yang berkaitan dengan soal dan pemahaman siswa mengenai hubungan antara jenis senyawa dengan larutan elektrolit dan nonelektrolit sudah cukup baik.

Pada kriteria penentuan proposisi persentase kelompok yang mendapatkan skor 4 sebanyak $20 \%$ dan skor 3 sebanyak $50 \%$. Hal ini menandakan sebagian besar kelompok sudah dapat menentukan proposisi yang tepat antar konsep. persentase kelompok yang mendapatkan skor 2 sebanyak 30\%. Kelompok yang mendapatkan skor 2 ini hanya dapat membuat tiga proposisi yang tepat dari minimal tujuh proposisi yang dapat dibuat. Persentase kelompok yang mendapatkan skor 1 sebanyak $0 \%$. Hal ini berarti tidak ada kelompok yang tidak dapat menentukan proposisi sama sekali.

Pada kriteria penentuan hirarki persentase terbesar berada pada skor 3 dan 2 masingmasing sebanyak 50\%. Beberapa kelompok yang mendapatkan skor 3 ini sudah memasukkan semua konsep yang dibutuhkan namun penempatannya masih kurang tepat sehingga hirarki tidak terlihat. Kelompok yang mendapatkan skor 2 pada peta konsep yang dibuat hanya memperlihatkan 1 level hirarki yang tepat.

Berdasarkan hasil tersebut dapat diketahui pada pembuatan peta konsep yang kedua ini pemahaman siswa mengenai hubungan antara jenis senyawa dengan larutan elektrolit dan nonelektrolit sudah cukup baik. Selain itu, juga terjadi perubahan terhadap kemampuan siswa dalam menentukan proposisi yang tepat dan juga hirarki.

Tabel 2. Hasil Perhitungan Uji Validitas Rubrik Penilaian Peta Konsep

\begin{tabular}{|c|l|c|r|l|}
\hline \multirow{2}{*}{ Soal } & Kriteria & $r_{\text {hitung }}$ & $\begin{array}{c}\mathrm{r}_{\text {tabel }} \\
(5 \%, 9)\end{array}$ & Ket \\
\hline \multirow{3}{*}{1} & Konsep & 0.773 & 0.632 & Valid \\
\cline { 2 - 5 } & Proposisi & 0.745 & 0.632 & Valid \\
\cline { 2 - 5 } & Hirarki & 0.658 & 0.632 & Valid \\
\cline { 2 - 5 } & Cross-link & 0.773 & 0.632 & Valid \\
\hline \multirow{3}{*}{2} & Konsep & 0.864 & 0.632 & Valid \\
\cline { 2 - 5 } & Proposisi & 0.67 & 0.632 & Valid \\
\cline { 2 - 5 } & Hirarki & 0.695 & 0.632 & Valid \\
\hline \multirow{3}{*}{3} & Konsep & 0.806 & 0.632 & Valid \\
\cline { 2 - 5 } & Proposisi & 0.782 & 0.632 & Valid \\
\cline { 2 - 5 } & Hirarki & 0.807 & 0.632 & Valid \\
\cline { 2 - 5 } & Cross-link & 0.662 & 0.632 & Valid \\
\hline
\end{tabular}

\section{c. Pembuatan peta konsep ketiga}

Berdasarkan hasil penilaian pada pembuatan peta konsep yang ketiga ini pada kriteria penentuan konsep yang relevan diketahui bahwa setiap kelompok sudah melakukan perbaikan terhadap peta konsep yang dibuat atau menambahkan konsepkonsep relevan lainnya yang ditandai dengan persentase kelompok yang mendapatkan skor 3 sebanyak $50 \%$ dan skor 4 sebanyak $50 \%$. Hal ini menandakan terjadinya perubahan pengetahuan dasar siswa dan kemampuan siswa dalam membedakan informasi. 
Tabel 3. Hasil Penilaian Kinerja Siswa Saat Proses Pembuatan Peta Konsep

\begin{tabular}{|c|c|c|c|c|c|c|}
\hline \multirow{2}{*}{ No Kriteria } & \multirow{2}{*}{ Penugasan } & \multicolumn{4}{|c|}{ Skor } \\
\cline { 3 - 6 } & & & 4 & 3 & 2 & 1 \\
\hline \multirow{2}{*}{1} & \multirow{2}{*}{ Manajemen Diri } & 1 & $44 \%$ & $29 \%$ & $27 \%$ & $0 \%$ \\
\cline { 3 - 6 } & & 2 & $56 \%$ & $33 \%$ & $10 \%$ & $0 \%$ \\
\hline \multirow{2}{*}{2} & \multirow{2}{*}{ Kontribusi dalam kelompok } & 1 & $33 \%$ & $35 \%$ & $31 \%$ & $0 \%$ \\
\cline { 3 - 6 } & & 2 & $42 \%$ & $29 \%$ & $29 \%$ & $0 \%$ \\
\hline \multirow{2}{*}{3} & \multirow{2}{*}{ Menghargai Pendapat } & 1 & $42 \%$ & $48 \%$ & $10 \%$ & $0 \%$ \\
\cline { 3 - 6 } & & 2 & $48 \%$ & $52 \%$ & $0 \%$ & $0 \%$ \\
\hline \multirow{2}{*}{4} & \multirow{2}{*}{ Manajemen waktu } & 2 & $21 \%$ & $79 \%$ & $0 \%$ & $0 \%$ \\
\hline \multirow{2}{*}{5} & \multirow{2}{*}{ Pemecahan masalah } & 1 & $50 \%$ & $50 \%$ & $0 \%$ & $0 \%$ \\
\cline { 3 - 7 } & & 2 & $40 \%$ & $35 \%$ & $21 \%$ & $4 \%$ \\
\hline \multirow{2}{*}{6} & \multirow{2}{*}{ Menganalisis Pertanyaan } & 1 & $17 \%$ & $40 \%$ & $42 \%$ & $2 \%$ \\
\cline { 3 - 7 } & & 2 & $10 \%$ & $56 \%$ & $33 \%$ & $0 \%$ \\
\hline \multirow{2}{*}{7} & \multirow{2}{*}{ Menyatakan Pendapat } & 1 & $42 \%$ & $25 \%$ & $23 \%$ & $10 \%$ \\
\cline { 3 - 7 } & & 2 & $35 \%$ & $31 \%$ & $23 \%$ & $10 \%$ \\
\hline \multirow{2}{*}{8} & \multirow{2}{*}{\begin{tabular}{l} 
Sikap positif terhadap \\
\cline { 3 - 6 }
\end{tabular}} & 1 & $46 \%$ & $46 \%$ & $8 \%$ & $0 \%$ \\
\cline { 3 - 7 } & 2 & $27 \%$ & $67 \%$ & $6 \%$ & $0 \%$ \\
\hline
\end{tabular}

Pada pembuatan peta konsep ketiga ini untuk kriteria penentuan hirarki tidak ada kelompok yang mendapatkan skor 1 maupun skor 2. Persentase kelompok yang mendapatkan skor 3 sebanyak $70 \%$ dan kelompok yang mendapatkan skor 4 sebanyak $30 \%$. Hal ini menunjukkan sudah adanya perbaikan pada peta konsep yang dibuat siswa. Peta konsep yang sebelumnya belum memperlihatkan hirarki atau hirarki belum tepat pada peta konsep ketiga ini sudah diperbaiki. Hasil ini menunjukkan sudah terjadinya perkembangan kemampuan siswa dalam menganalisis konsep yang lebih umum dan konsep yang lebih khusus.

Pada kriteria penentuan proposisi persentase kelompok yang mendapatkan skor 4 sebanyak $20 \%$ dan skor 3 sebanyak $60 \%$. Hal ini menandakan sebagian besar kelompok sudah melakukan perbaikan terhadap beberapa proposisi yang masih salah pada pembuatan peta konsep sebelumnya. Persentase kelompok yang mendapatkan skor 2 sebanyak 20\%. Kelompok ini tidak melakukan perbaikan terhadap peta konsep yang telah dibuat sebelumnya atau perbaikan yang dilakukan hanya sedikit sekali.
Pada kriteria penentuan hubungan silang persentase kelompok yang mendapatkan skor 4 sebanyak $0 \%$. Hal ini menandakan siswa masih merasa kesulitan untuk membuat hubungan silang antar konsep. Sedangkan, hanya 1 kelompok yang mendapatkan skor 3 . Kelompok ini sudah mampu membuat 4 hubungan silang antar konsep dengan kata penghubung yang tepat, Persentase kelompok yang mendapatkan skor 2 (terdapat 2-3 hubungan silang yang tepat) sebanyak $80 \%$. Pada peta konsep yang kelompok ini buat sudah menunjukkan adanya hubungan silang yang sebelumnya belum ada di peta konsep pertama maupun kedua. Sedangkan kelompok yang mendapatkan skor 1 sebanyak 10\%. Pada peta konsep yang dibuat kelompok ini sudah memperlihatkan adanya dua hubungan silang, namun kata penghubung yang digunakan masih belum tepat. Hasil ini menunjukkan terjadinya perubahan kemampuan siswa dalam mensintesis dan mengevaluasi meskipun hasil yang didapat belum signifikan.

Berdasarkan hasil penelitian tersebut dapat diketahui bahwa terjadi perubahan persentase ketercapaian skor siswa pada setiap kriteria penilaian. Perubahan ini menunjukkan 
terjadinya perkembangan kemampuan berpikir tingkat tinggi siswa, meskipun perkembangan yang dihasilkan belum signifikan, karena untuk dapat mengembangkan kemampuan berpikir diperlukan waktu untuk memperlajarinya. sebanyak 29\%. Pada penugasan kedua persentase siswa yang mendapatkan skor 4 sebanyak $56 \%$ dan skor 3 sebanyak 33\%. Hal ini menunjukkan sebagian besar siswa sudah mampu mengatur dirinya dalam hal fokus terhadap tugas.

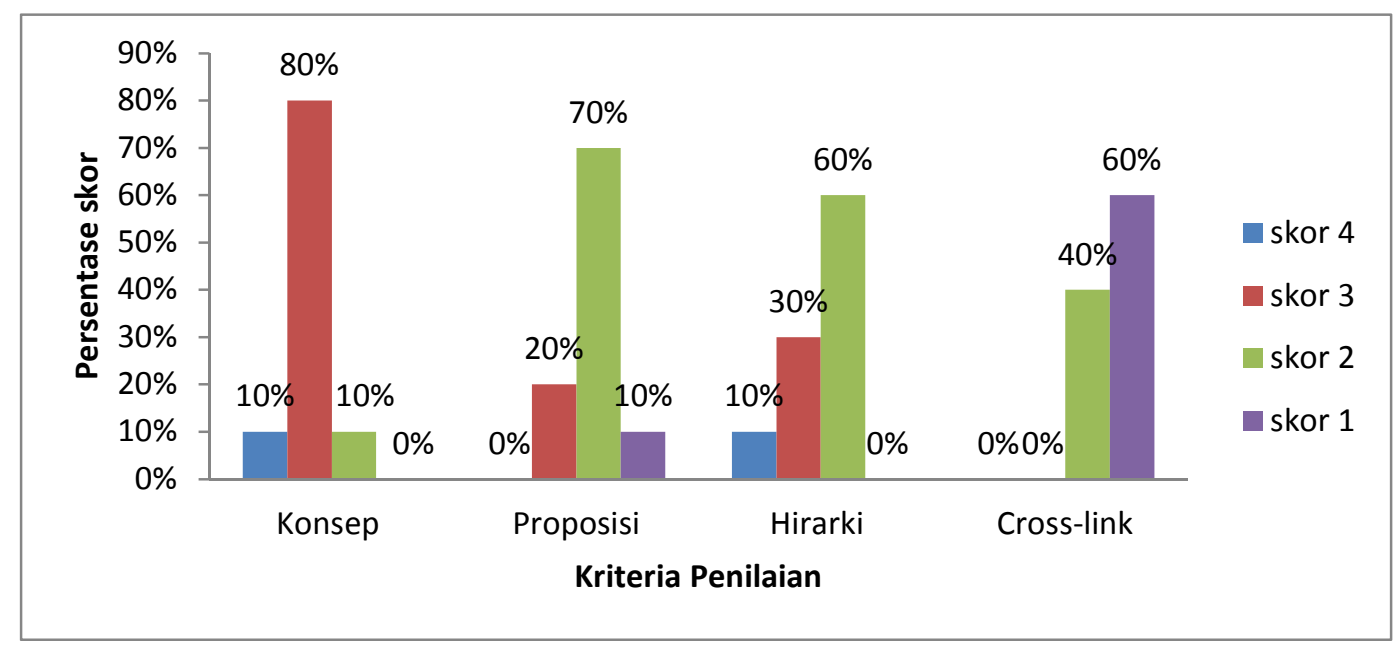

Gambar 1. Hasil Penilaian Peta Konsep Pertama

Oleh karena itu, untuk dapat mengembangkan kemampuan berpikir tingkat tinggi harus dilakukan secara berkelanjutan dan diperlukan usaha dari guru maupun siswa. Dalam pembuatan peta konsep ini sebagian besar siswa masih bingung untuk menentukan konsep-konsep yang saling berhubungan, menentukan kata penghubung yang tepat, dan menentukan hubungan silang antar konsep.

\section{2) Penilaian Kinerja Siswa Saat Proses \\ Pembuatan Peta Konsep Secara Berkelompok}

Penilaian kinerja siswa didasarkan pada beberapa kriteria, yaitu manajemen diri, kontribusi dalam kelompok, menghargai pendapat, manajemen waktu, pemecahan masalah, menyatakan pendapat, analisis pertanyaan, dan sikap positif terhadap tugas.

Kriteria manajemen diri siswa dilihat apakah siswa mampu fokus dalam pengerjaan tugas atau mengerjakan hal lainnya. Pada penugasan pertama persentase siswa yang mendapatkan skor 4 sebanyak $44 \%$ dan skor 3
Kriteria konstribusi dalam kelompok memperlihatkan kemampuan kerjasama siswa. Pada penugasan pertama persentase siswa yang mendapatkan skor 4 sebanyak 33\% dan skor 3 sebanyak 35\%. Pada penugasan kedua persentase siswa yang mendapatkan skor 4 sebanyak $42 \%$ dan skor 3 sebanyak 29\%. Hal ini menunjukkan sebagian besar siswa sudah mampu bekerjasama dalam kelompok

Kriteria menghargai pendapat dalam penelitian ini adalah kemampuan siswa dalam menghargai pendapat atau saran yang diberikan teman sekelompok lainnya. Pada penugasan pertama persentase siswa yang mendapatkan skor 4 sebanyak $42 \%$ dan skor 3 sebanyak 48\%. Pada penugasan kedua persentase siswa yang mendapatkan skor 4 sebanyak $48 \%$ dan skor 3 sebanyak $52 \%$. Hal ini menunjukkan siswa sudah memiliki sikap yang baik dalam hal menghargai pendapat.

Kriteria manajemen waktu dalam penelitian ini adalah kemampuan siswa untuk mempergunakan waktu sebaik mungkin agar 


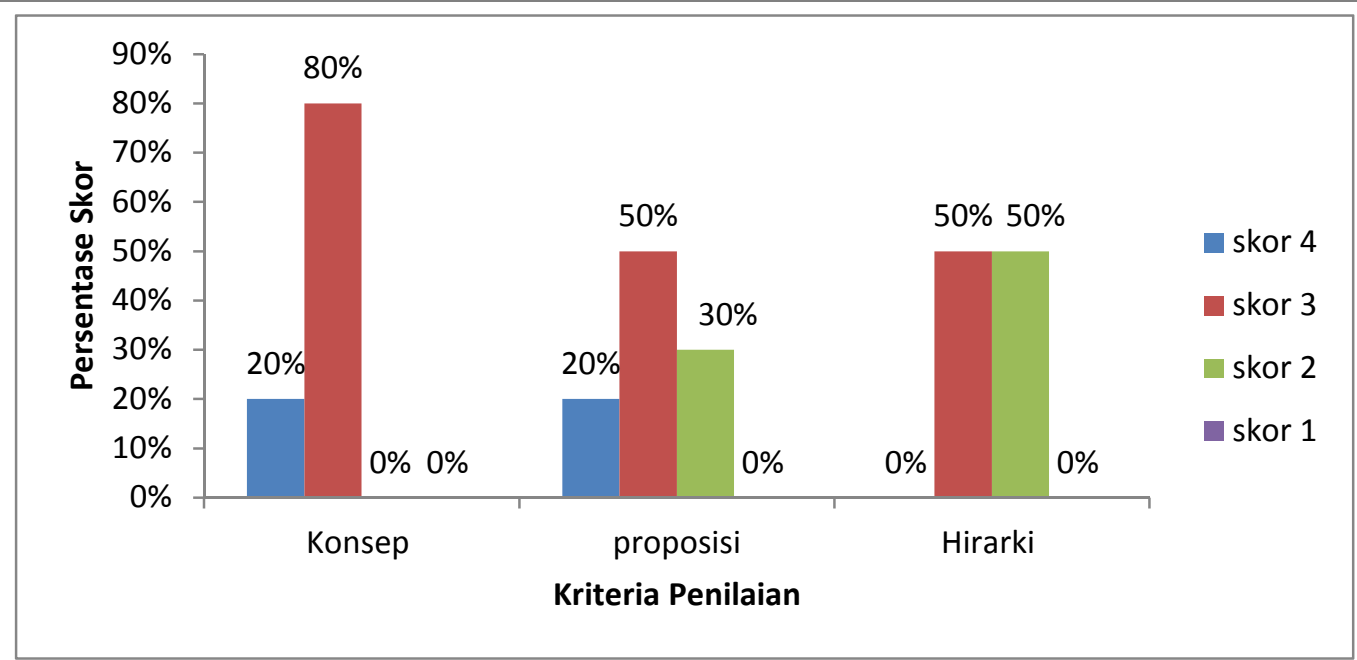

Gambar 2. Hasil Penilaian Peta Konsep Kedua

peta konsep dapat dikumpulkan tepat pada waktunya. Pada penugasan pertama persentase siswa yang mendapatkan skor 4 sebanyak 21\% dan skor 3 sebanyak 79\%. Pada penugasan kedua persentase siswa yang mendapatkan skor 4 sebanyak $50 \%$ dan skor 3 sebanyak 50\%. Hal ini menandakan siswa sudah mampu menggunakan waktu dengan baik sehingga tugas selesai tepat waktu.

Kriteria pemecahan masalah dalam penelitian ini berarti kemampuan siswa dalam mencari dan menyarankan solusi dalam pembuatan peta konsep. Pada penugasan pertama persentase siswa yang mendapatkan skor 4 sebanyak $40 \%$ dan skor 3 sebanyak $21 \%$. Pada penugasan kedua persentase siswa yang mendapatkan skor 4 sebanyak $40 \%$ dan skor 3 sebanyak 35\%. Hal ini berarti sebagian besar siswa sudah mampu untuk mencari dan menyarankan solusi dari soal yang diberikan.

Kriteria kemampuan menganalisis pertanyaan dalam penelitian ini yaitu kemampuan siswa untuk memahami maksud dari soal sehingga mengetahui batasan peta konsep yang akan dibuat. Pada dua kali penugasan persentase terbesar siswa berada pada skor 3 dan skor 2. Pada penugasan pertama siswa yang mendapatkan skor 3 sebanyak 40\% dan skor 2 sebanyak 42\%. Pada penugasan kedua siswa yang mendapatkan skor 3 sebanyak $56 \%$ dan skor 3 sebanyak
33\%. Hasil ini menandakan siswa masih mengalami kesulitan dalam menganalisis soal. Penilaian kemampuan menyatakan pendapat dalam penelitian ini dilihat dari seberapa sering siswa mampu untuk mengutarakan pendapatnya. Pada penugasan pertama persentase siswa yang mendapatkan skor 4 sebanyak $42 \%$ dan skor 3 sebanyak $25 \%$. Pada penugasan kedua persentase siswa yang mendapatkan skor 4 sebanyak $35 \%$ dan skor 3 sebanyak 31\%. Hasil ini menunjukkan sebagian besar siswa sudah mampu untuk menyetakan pendapatnya.

Sikap positif terhadap tugas dalam penelitian ini adalah mau menghargai pekerjaan orang lain dan kemauan untuk mengerjakan tugas yang diberikan. Pada penugasan pertama persentase siswa yang mendapatkan skor 4 sebanyak $46 \%$ dan skor 3 sebanyak $46 \%$. Pada penugasan yang kedua persentase terbesar siswa berada pada skor 3 yaitu sebanyak 67\%. Pada penugasan kedua lebih banyak siswa yang mengeluh tentang pengerjaan tugas yang menandakan sikap positif siswa terhadap tugas masih kurang baik.

\section{Kesimpulan dan Saran}

Berdasarkan hasil penelitian, dapat diketahui bahwa secara umum pada tiga kali pembuatan peta konsep terjadi perubahan persentase ketercapaian skor siswa pada 


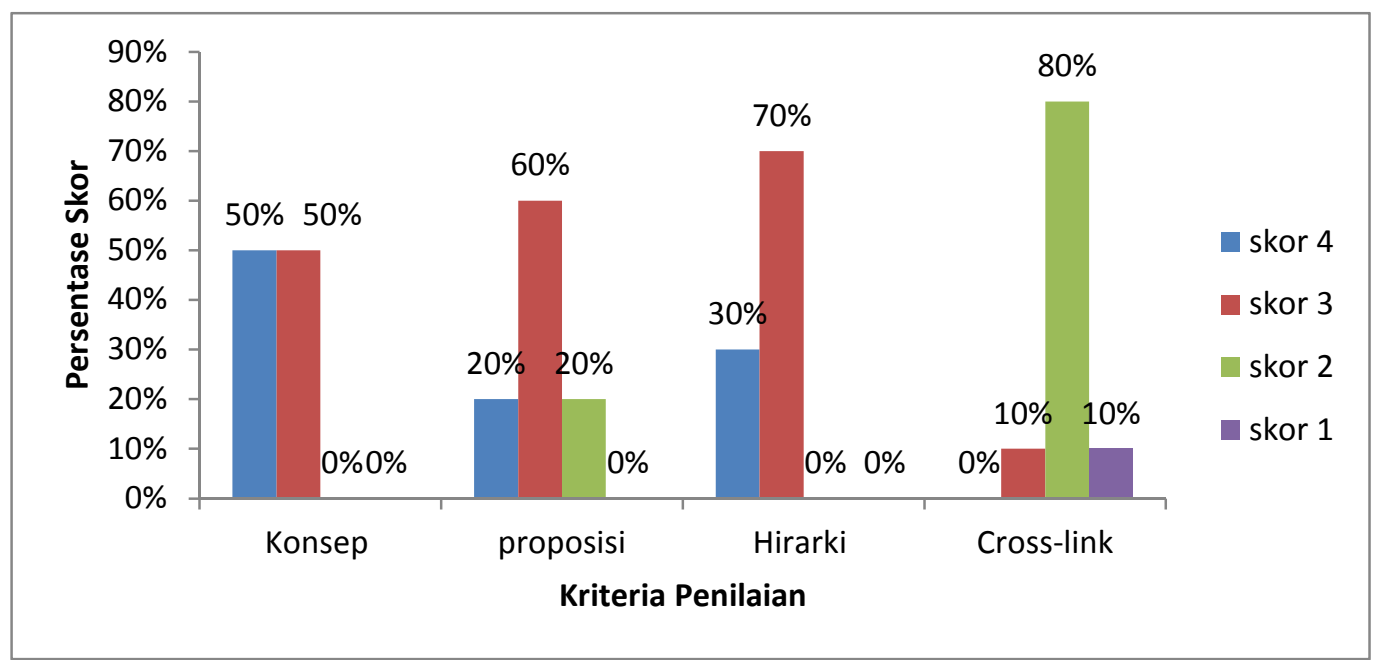

Gambar 3. Hasil Penilaian Peta Konsep Ketiga

setiap kriteria penilaian peta konsep, yaitu penentuan konsep yang sesuai, proposisi, hirarki, dan hubungan silang. Sehingga, dapat disimpulkan dengan menugaskan siswa membuat peta konsep dapat mengembangkan kemampuan berpikir tingkat tinggi siswa. Selain itu, berdasarkan hasil penilaian kinerja selama dua kali proses pembuatan peta konsep diketahui siswa sudah memiliki kemampuan manajemen diri, kerjasama, menghargai pendapat, manajemen waktu, dan menyatakan pendapat yang sudah baik. Namun sebagian besar siswa masih mengalami kesulitan dalam menganalisis pertanyaan, dan sikap positif siswa terhadap tugas masih kurang baik.

Kesulitan siswa dalam membuat peta konsep dapat terjadi karena; (i) siswa memang tidak memahami materi; (ii) siswa tidak mampu melihat hubungan antara berbagai konsep pada materi tersebut; (iii) siswa tidak mampu menentukan kata penghubung antara konsep-konsep yang saling berkaitan; (iv)siswa tidak mampu untuk menentukan konsepkonsep dalam suatu hirarki yang berhubungan dengan konsep pada hirarki lain pada sebuah peta konsep.
Saran-saran yang diajukan dalam penelitian ini, (1) Bagi guru dapat menggunakan peta konsep sebagai penilaian formatif dan untuk dapat mengembangkan kemampuan berpikir siswa pelaksanaan pembelajaran yang dilakukan juga harus berpusat pada siswa. Selain itu, pembuatan peta konsep ini harus dilaksanakan secara kontinu. Bagi peneliti lain, latihan peta konsep yang diberikan pada siswa dapat dilakukan lebih dari tiga kali agar pada saat penilaian siswa telah memiliki kemampuan yang baik dalam membuat peta konsep. (2) Bagi peneliti lain, pada setiap akhir proses pembelajaran dapat melakukan refleksi sebagai bahan pertimbangan untuk perbaikan proses pembelajaran selanjutnya, (3) Peneliti lain dapat melakukan penelitian mengenai pengembangan instrumen penilaian kemampuan berpikir tingkat tinggi siswa dengan menggunakan peta konsep.

\section{Penghargaan}

Penulis mengucapkan terima kasih kepada SMAN 4 Bekasi yang telah mengizinkan penulis untuk melakukan penelitian

\section{Daftar Pustaka}

[1] Baker, Eva. 1989. Higher Order Assessment and Indicators of Learning. UCLA Center for Research on Evaluation, Standards, and Student Testing.

[2] Dahar, Ratna Wilis. 1989. Teori-teori Belajar. Jakarta: Erlangga 
[3] Djaali dan Muljono, P. 2008. Pengukuran Dalam Bidang Pendidikan. Jakarta: Grasindo.

[4] Limbach, Barbara. 2000. Developing Higher Level Thinking. Journal of Instructional Pedagogies.

[5] Muslich, Masnur. 2010. Penilaian Berbasis Kelas dan Kompetensi. Bandung: PT. Refika Aditama.

[6] Novak dan Alberto. 2008. The Theory Underlying Concept Maps and How to Construct and Use Them. Pensacola: Florida Institute for Human and Machine Cognition

[7] Nurbaity dan Sihombing .2003. Perencanaan, Pengelolaan, dan Evaluasi Pengajaran (PPEP). Jakarta: Jurusan Kimia FMIPA UNJ.

[8] Rusilowati, Ani. 2011. Pengembangan Concept Mapping Assesment untuk Mengukur Kemampuan Mahasiswa Mengkonstruk Konsep Elektronika. Jurnal Pendidikan Fisika Indonesia 7 (2011) 13-16. Semarang: Unnes.

[9] Siregar, Eveline. 2008. Teori Belajar dan Pembelajaran. Jakarta: Fakultas Ilmu Pendidikan Universitas Negeri Jakarta.

[10] Thomas, Alice dan Glenda. Higher Oder Thinking. 1999. http://www.cdl.org/resource library/articles/highorderthinking.php. Diakses tanggal 10 mei 2012 pukul 02.11 WIB.

[11] Wendy. 2007. Using Concept Maps to Explore the Conceptual Knowledge of Technology Student. The Ohio State University

[12] White, Hal. 2011. How to Construct a Concept Map. http://www.udel.edu/chem/white/teaching/ConceptMap.html. Diakses tanggal 1 Februari 2012 pukul 09.25 WIB. 